\title{
Characterization and Phytochemical Screening of Meniran (Phyllanthus niruri Linn) Extract's Nanoparticles Used Ball Mill Method
}

\author{
Emy Koestanti Sabdoningrum*, Sri Hidanah, Sri Chusniati, Soeharsono
}

Emy Koestanti Sabdoningrum*, Sri Hidanah, Sri Chusniati, Soeharsono

Faculty of Veterinary Medicine, Universitas Airlangga, Surabaya, INDONESIA.

\section{Correspondence}

\section{Emy Koestanti Sabdoningrum}

Faculty of Veterinary Medicine, Universitas Airlangga, Surabaya, INDONESIA.

E-mail: emykoestanti10@gmail.com

History

- Submission Date: 15-09-2021;

- Review completed: 03-10-2021;

- Accepted Date: 11-10-2021.

DOI : $10.5530 /$ j. 2021.13 .200

Article Available online http://www.phcogj.com/v13/i6

Copyright

(C) 2021 Phcogj.Com. This is an openaccess article distributed under the terms of the Creative Commons Attribution 4.0 International license.

\begin{abstract}
The aim of this study was to study the characterization and phytochemical screening of meniran (Phyllanthus niruri linn) extract's nanoparticles used ball mill method. The effect of herbal products would be maximized, a formulation that able to increase solubility, stability, bioavailability, and a targeted system was needed so the use of simplicia would be more effective. One of alternative solutions to this problem was to make the preparation of meniran extract in the form of nanoparticles. Nanoparticles made it easier for extract to be absorbed in blood plasma and were more effective in achieving the target drug itself. The manufacture of meniran nanoparticles used ball mill method. Then, meniran extract nanoparticles characterization and phytochemical screening were carried out. Meniran (Phyllanthus niruri Linn) extract nanoparticle characterization consisted of size, used Particle Size Analyzer (PSA), and morphology, used Scaning Electron Microscope (SEM). Phytochemical screening of meniran extract nanoparticles used qualitative screening by reagent test. The results showed that the meniran extract nanoparticles produced an average size of $192.6 \mathrm{~nm}$. The averange shape of particle was imperfectly amorphous and the dominant composition was Carbon (C). Phytochemical screening showed the content of flavonoids, tannins, saponins, terpenoids and alkaloids.

Key words: Phyllanthus niruri, Nanoparticle, Phytochemical compound, Biological production
\end{abstract}

\section{INTRODUCTION}

Meniran (Phyllanthus niruri Linn.) contains active compounds such as flavonoid, tannin, alkaloid, saponin and terpenoid ${ }^{1}$. Flavonoid have some benefits, including anticancer, antioxidant, antiinflammatory, and antiviral properties ${ }^{2}$. Tannin is efficacious as antioxidants and antibacterial agents ${ }^{3}$. Saponin has the ability as antimicrobials, while terpenoid is able to inhibit the activity of Escherecia coli and Staphylococcus aureus. The obstacle in the application of plant extracts is their low solubility in the digestive tract so that absorption in blood plasma is low ${ }^{5}$.To optimize the effect of herbal medicines, it is necessary to develop a formulation that can improve solubility, stability, bioavailability, and a system that focuses on application effectiveness. The use of nanoparticles as drug carriers and drug delivery systems has developed in recent years. The small size of particle has a number of advantages over conventional carrier systems: higher stability against gravity aggregation and separation; higher optical clarity; and increased bioavailability ${ }^{6}$. The reduced particle size causes bioactive agents to be absorbed easily, able to penetrate the mucus layer, or be absorbed directly by cells ${ }^{7}$. Therefore, in this study, we aim to review the characteristics and phytochemical content of nanoparticles extracts of meniran (Phyllanthus niruri Linn.) using the ball mill method.

\section{MATERIALS AND METHODS}

\section{Extraction of Meniran (Phyllanthus niruri Linn.)}

Meniran was macerated using $70 \%$ ethanol solvent. The mixture was then soaked for 24 hours and filtered. Maceration was repeated three times until clear colored filtrate was obtained. The filtrate obtained was concentrated with a rotary evaporator at $50{ }^{\circ} \mathrm{C}$.

\section{Phytochemical Screening}

Alkaloid test: Conducted by the method of Mayer, Wagner and Dragendorff. A sample of $3 \mathrm{~mL}$ was added with $5 \mathrm{~mL}$ of $2 \mathrm{M} \mathrm{HCl}$, stirred and cooled at room temperature. After that, $0.5 \mathrm{~g}$ of $\mathrm{NaCl}$ was added to the already cool sample then stirred and filtered. The filtrate obtained was added with 3 drops of $2 \mathrm{M} \mathrm{HCl}$, then separated into 4 parts (A, B, C, D). Filtrate A was used as blank, filtrate B was added to Mayer's reagent, filtrate $C$ was to be added to Wagner reagent, while filtrate $\mathrm{D}$ was used for the confirmation test. Precipitate would be formed on the addition of Mayer and Wagner reagents, when identification indicates the presence of alkaloid. Confirmation test was carried out by adding 25\% ammonia to filtrate D until PH changed to 8-9. Then chloroform was added, and evaporated in water bath. Then $2 \mathrm{M} \mathrm{HCl}$ was added, stirred and filtered. The filtrate was divided into 3 parts. Filtrate A was used as blank, filtrate B was tested with Mayer's reagent, while filtrate $\mathrm{C}$ was tested with Dragendorff's reagent. The formation of a precipitate indicated the presence of alkaloid.

Tannin test: 2 grams of sample was put into a 500 $\mathrm{mL}$ boiling flask, then added $350 \mathrm{~mL}$ of distilled water and refluxed for 3 hours. The sample was cooled and transferred into $500 \mathrm{ml}$ volumetric flask, then filtered and $2 \mathrm{ml}$ of the filtrate was put into a $100 \mathrm{ml}$ volumetric flask. $2 \mathrm{ml}$ of Folin Denis reagent and $5 \mathrm{ml}$ of saturated $\mathrm{Na}_{2} \mathrm{CO}_{3}$ were added and allowed to stand for 40 minutes then the absorbance was measured at wavelength of $725 \mathrm{~nm}$. 
100 grams of $\mathrm{Na}_{2} \mathrm{WO}_{4}, 20$ grams of phospomolybdic acid and $50 \mathrm{ml}$ of $85 \%$ phosphoric acid were added to $750 \mathrm{ml}$ of distilled water, then the mixture was refluxed for 3 hours, cooled and added to 1 liter of distilled water. 3 grams of anhydrous $\mathrm{Na}_{2} \mathrm{CO}_{3}$ was added to $100 \mathrm{ml}$ of distilled water at $70-80^{\circ} \mathrm{C}$, stirred and cooled over night.

Saponin test: Used the Forth method, by inserting $2 \mathrm{~mL}$ of the sample into a test tube, then $10 \mathrm{~mL}$ of distilled water was added and shaken for 30 seconds, the changes that occurred was ovserved. the indication of the presence of saponin was the formation of solid foam (not lost for 30 seconds),

Flavonoid test: $3 \mathrm{~mL}$ of the sample was evaporated and washed with hexane until it was clear. The residue was dissolved in $20 \mathrm{~mL}$ of ethanol and then filtered. The filtrate was divided into 4 parts (A, B, C and D). Filtrate A as blank, filtrate $\mathrm{B}$ added $0.5 \mathrm{~mL}$ of concentrated $\mathrm{HCl}$ then heated in a water bath, indicates a positive result (Bate Smith-Metchalf method). if there is a color change frpm dark red to purple. The filtrate $\mathrm{C}$ was added with $0.5 \mathrm{~mL}$ of $\mathrm{HCl}$ and $\mathrm{Mg}$ metal and then the color change was observed (Wilstater method). Red to orange colors are given by flavone compounds, dark red colors are given by flavonols or flavonones, green to blue colors are given by aglycones or glycosides.

Terpenoid test: Terpenoid test used the Liebermann-Bouchard method. The reaction of triterpenoid with Liebermann's reagent produced a red-purple color while steroid gave a green-blue color.

\section{Manufacture of Meniran (Phyllanthus niruri Linn.) Extract Nanoparticles}

Simplicia meniran was macerated with $90 \%$ methanol and soaked for 3 x 24 hours. Then the mixture was filtered and the obtained filtrate was concentrated with a rotary evaporator at $500^{\circ} \mathrm{C}$. The extract was diluted to $5 \%, 10 \%$ and $20 \%$ with $0.5 \%$ CMCNa. Meniran extract with each concentration of $5 \%, 10 \%$ and $20 \%$ was taken $25 \mathrm{ml}$ and then added to 250 grams of minerals containing amino acids and multivitamins, then nanoparticles synthesis was carried out by top-down milling method. The powder-loaded ball mill and the ambient balls are rotated at a speed of $1000 \mathrm{rpm}$.

\section{Characterization of Meniran (Phyllanthus niruri Linn.) Extract Nanoparticles}

Characterization used Particle Size Analyzer (PSA) and Scanning Electron Microscopy (SEM). On particle size characterization by PSA, the specimen was dissolved in $3 \mathrm{ml}$ of ethanol. The solute was then put into a tube with a maximum solution height of $15 \mathrm{~mm}$. Then the diameter distribution of the specimens was measured using the VASCO Nano Particle Analyzer. This examination was carried out based on the Dynamic Light Scattering (DLS) method using the Zetasizer Nano ZS (Malvern Instruments).

In the morphological characterization by SEM, the powders of meniran nano extract were placed on the butt using a double-sided tape. The powders were conditioned to be electrically conductive with a thin layer of platinum beam from the coating for 30 seconds at pressure below $2 \mathrm{~Pa}$ and current strength of $30 \mathrm{~mA}$. Photographs were taken at electron voltage of $10 \mathrm{kV}$ at the desired magnification.

\section{RESULTS AND DISCUSSION}

The results of the phytochemical screening of meniran (Phyllanthus niruri Linn) can be seen in Figure 1.

The results showed that meniran (Phyllanthus niruri Linn) positive contained compounds: flavonoid, tannin, saponin, trepenoid and alkaloid. Flavonoid showed color change to orange. Tannin showed color change to blackish green. The saponin formed foam for about

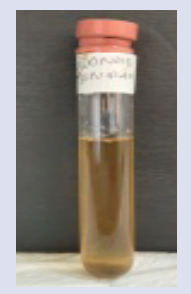

A

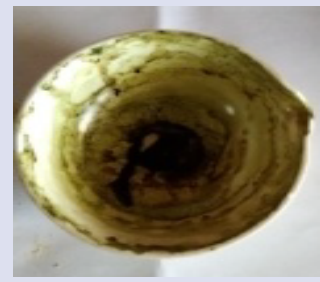

D

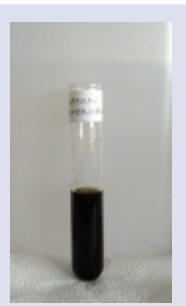

B

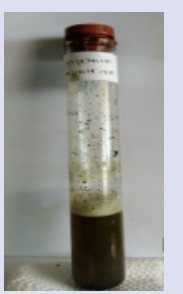

C

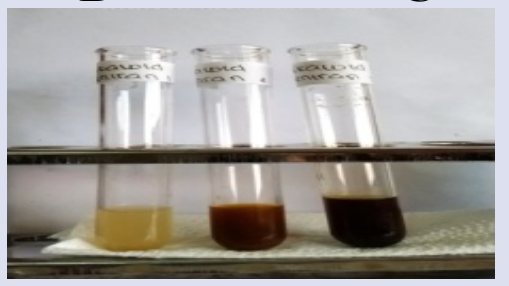

$\mathbf{E}$

Figure 1. Meniran (Phyllanthus niruri Linn) phytochemical screening results A. Flavonoid, B. Tannin, C. Saponin, D. Trepenoid, E. Alkaloid.

10 minutes and when 1 drop of hydrochloric acid was added, the foam did not disappear. Terpenoid showed color change to red. Examination of alkaloid used three tests with results: Meyer test formed white precipitate, Dragendrof test formed brown precipitate and Wagner test formed a brown precipitate.

The components contained in the meniran (Phyllanthus niruri Linn.) were analyzed for its compounds by color test with several reagents for flavonoid, tannin, saponin, trepenoid and alkaloid. The specific reagents used were mostly polar so they could interact with the sample based on the principle of 'like dissolves like's. The formation of precipitates in the Mayer, Wagner and Dragendorff tests meant that in the meniran (Phyllanthus niruri Linn.) there was alkaloid. Alkaloid had alkaline properties and was in the form of salts in plants, so acidic water was chosen to extract alkaloids'. Treatment with $\mathrm{NaCl}$ before the addition of reagents was carried out to remove protein. The presence of protein in the compound could form precipitation and false positive results in some compound tests when Wagner reagent was added ${ }^{10}$

Positive result of alkaloid in the Mayer test was indicated by the formation of a white precipitate. It was thought that the precipitate was a potassium-alkaloid complex. On the manufacture of Mayer's reagent, solution of mercury(II) chloride plus potassium iodide would react to form a red precipitate of mercury(II) iodide. Potassium tetraiodomercurate(II) would be formed when the excessive potassium iodide was added ${ }^{11}$. Alkaloid contained nitrogen atoms that had lone pair of electrons so that they could be used to form coordinate covalent bonds with metal ions ${ }^{12}$. In the alkaloid test with Mayer reagent, it was estimated that the nitrogen in the alkaloid would react with the metal ion $\mathrm{K}+$ from potassium tetraiodomercurate(II) to form a precipitated potassium-alkaloid complex. Positive result of alkaloid in the Wagner test was indicated by the formation of a light brown to yellow precipitate. It is estimated that the precipitate was potassium-alkaloid. In the preparation of Wagner reagent, iodine reacted with I- ions of potassium iodide to produce I3- ions which were brown in color. In the Wagner test, metal ions $\mathrm{K}+$ would form coordinate covalent bonds with nitrogen in the alkaloids to form a precipitated potassiumalkaloid complex. Positive result of alkaloid in Dragendorff test was also indicated by the formation of a light brown to yellow precipitate. The precipitate was a potassium alkaloid. In the manufacture of Dragendorff reagent, bismuth nitrate was dissolved in $\mathrm{HCl}$ so that no hydrolysis reaction occured because bismuth salts ere easily hydrolyzed to form bismuth ions $(\mathrm{BiO}+)$. Furthermore, the $\mathrm{Bi} 3+$ ion from bismuth 
nitrate reacted with potassium iodide to form a black precipitate of Bismuth(III) iodide which then dissolved in excess potassium iodide to form potassium tetraiodobismuthate ${ }^{13}$. In the alkaloid test with Dragendorff reagent, nitrogen was used to form a coordinate covalent bond with $\mathrm{K}+$ which was a metal ion ${ }^{14}$. To confirm the positive results of alkaloids obtained, Mayer, Wagner and Dragendorff tests were performed on the $\mathrm{CHCl} 3$ fraction and the water fraction of the sample.

On the tannin test, positive results were obtained, the presence of tannin would precipitate protein in gelatin. Tannin reacted with gelatin to form stable copolymers that were insoluble in water ${ }^{15}$. This reaction was more sensitive with the addition of $\mathrm{NaCl}$ to enhance the saltiness of the tannin-gelatin. The appearance of foam in the Forth test indicated the presence of glycosides that had the ability to form foam in water which was hydrolyzed into glucose and its aglycones ${ }^{16}$. The foam formation reaction showed a positive result of the saponin test. In addition to the Forth test, the Lieberman-Burchard test was also carried out which is a characteristic test for unsaturated sterols and triterpenes ${ }^{17}$.

The results of the Particle Size Analyzer (PSA) test on the particle size and size distribution of meniran extract nanoparticles made using the ball milling method at $1000 \mathrm{rpm}$ are shown in Table 1.

Compositions in the nanoparticles formulation, the larger the particle size formed.

The results of the SEM test with magnification of $10000 \mathrm{x}$ with scale of $14 \mathrm{~m}=1000 \mathrm{~nm}$ showed the surface morphology of the carbon particles and the sizes of the carbon particles can be seen in Figure 2 .

The results of the Particle Size Analyzer (PSA) test on the production of meniran (Phyllanthus niruri Linn) extract nanoparticles with the ball milling method at $1000 \mathrm{rpm}$ could be seen to produce an average of $192.6 \mathrm{~nm}$ of meniran extract nanoparticles. Characterization conducted by PSA showed samples with nano size. Nanoparticles were solid colloidal particles with a diameter of 1-1000 $\mathrm{nm}^{18}$. Nanoparticles synthesized from polymeric or macromolecular materials generally had size range between 1 to $1000 \mathrm{~nm}^{19}$. The required nanoparticle size in the drug delivery system was $50-300 \mathrm{~nm}^{20}$. Particle size played an important role in determining drug distribution and release, targeting ability of nanoparticle systems, and toxicity ${ }^{21}$.

Table 1: Particle Size of Synthesis Result of Meniran (Phyllanthus niruri Linn) Extract Nanoparticles at Several Doses.

\begin{tabular}{ccc} 
Concentration & Particle Size $(\mathrm{nm})$ & Polydispersity Index (Pdl) \\
\hline P1(5\%) & 192,6 & 0,903 \\
P2(10\%) & 196,3 & 0,918 \\
P3(20\%) & 206,4 & 0,804
\end{tabular}

The difference in particle size indicated that the more compound

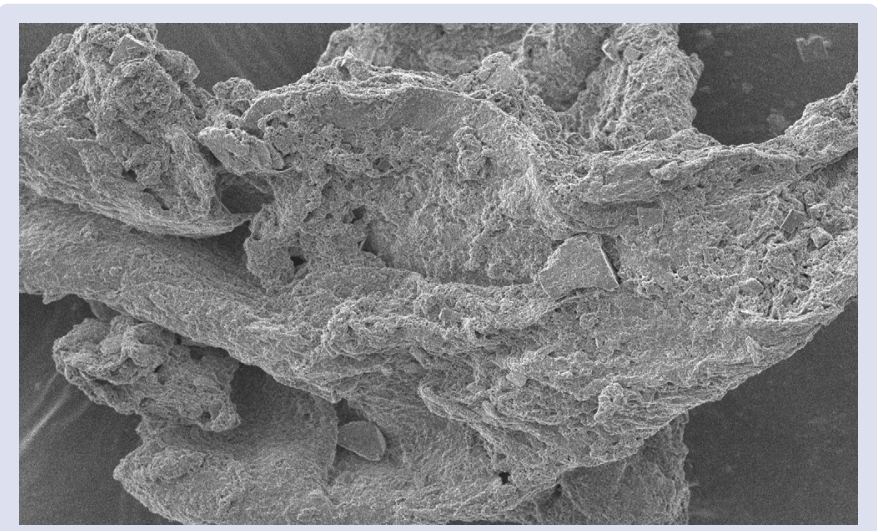

Figure 2. Morphology of Meniran (Phyllanthus niruri Linn) Extract Nanoparticles using 1000x Magnification SEM.
Synthesis of nanoparticles in the top-down method was conducted by milling. Synthesis of nanoparticles by grinding different elements in an inert atmosphere used milling and annealing. The top-down method was known to have the advantages of efficient method and phase formation at low temperatures ${ }^{22}$.

The results of Scanning Electron Microscopy (SEM) showed that from the overall production of nanoparticles, it could be seen that some of the nanoparticles were already nano-sized. Scanning Electron Microscopy (SEM) was a method of researching the surface structure of a sample. This instrument provided a large depth of field, i.e. the sample area could be viewed in a sufficiently large focus. SEM had the advantage of a relatively wide magnification range. The images produced by this instrument appeared in three-dimensional form, made it more attractive to human eye and made it easier for researchers to analyze ${ }^{23}$. Scanning Electron Microscopy (SEM) provided detailed surface information by tracing the sample in a raster pattern with an electron beam. The scatter pattern created by the interaction of the sample with the electron beam produces information about the size, shape, texture, and composition of the sample ${ }^{24}$. SEM results of meniran (Phyllanthus niruri Linn) extract nanoparticles showed amorphous morphology and the presence of agglomeration in milling treatment had a small particle size morphology.

Advantages of using nanoparticles: controlled size, narrow size distribution, selectivity and precision ${ }^{25}$. The antibacterial ability of nanoparticles is influenced by the physical characteristics of the nanomaterial such as size, shape, and surface properties. The ratio of surface area to volume increases with the smaller particle size so that the nanoparticles have a stronger antibacterial ability. The smaller the nanoparticle size, the greater the antimicrobial effect.

\section{CONCLUSION}

1. Phytochemical screening of Meniran (Phyllanthus niruri Linn) extract contains of flavonoid, tannin, saponin, tritepenoid, and alkaloid.

2. Synthesis of meniran (Phyllanthus niruri Linn) extract nanoparticles by ball milling method produces an average of $192.6 \mathrm{~nm}$ of meniran extract nanoparticles. The average shape particle is imperfect amorphous with the dominant composition is Carbon (C).

\section{ACKNOWLEDGMENT}

We thank EJA, Indonesia for editing the manuscript.

We thank Universitas Airlangga, Indonesia for the financial support.

\section{DISCLOSURE STATEMENT}

No conflicts of interest.

\section{REFERENCES}

1. Feliciana A, Stefanus A, Evanda F, Anthony PY, Suryanti I, et al. (2019). Effect of Phyllanthus niruri Extract on Low Density Lipoprotein of Dyslipidemic White Rats (Rattus norvegicus). Herb Med Vol.5 No.2:6.

2. Ullah, A., S. Munir, S.L. Badshah, N. Khan, L. Ghani, B.G. Poulson, A.H. Emwas and M. Jaremko. 2020. Important Flavonoids and Their Role as a Therapeutic Agent. Molecules. Molecules. 25(22): 5243.

3. Hasima, D. N. Faridahb and D. A. Kurniawatic. 2015. Antibacterial activity of Parkia speciosa Hassk. peel to Escherichia coli and Staphylococcus aureus bacteria. Journal of Chemical and Pharmaceutical Research. 7(4):239-243.

4. Ozawa M, Baba K, Shimizu Y, et al. Comparison of in vitro activities and pharmacokinetics/pharmacodynamics estimations of veterinary fluoroquinolones against avian pathogenic Escherichia coli isolates. Microbial Drug Resistance. 2010; 16(4): 327-332. 
5. Prado Barragán, L. A., J.J.B. Figueroa, L.V. Rodríguez Durán, C.N. Aguilar González and C. Hennigs. 2016. Fermentative Production Methods. Biotransformation of Agricultural Waste and By-Products. 189-217.

6. Joye, I. J., G. Davidov-Pardo dan D.J. McClements. 2014. Nanotechnology for increased micronutrient bioavailability. Trends in Food Science \& Technology, 40(2), 168-182.

7. Jafari, S. M., and D.J. McClements, D. J. 2017. Nanotechnology Approaches for Increasing Nutrient Bioavailability. Advances in Food and Nutrition Research.1-30.

8. Lumowa, S. V. and S. Bardin. 2018. Phytochemical Test of Kepok Banana Peel (Musa paradisiacaL.) Natural Ingredients as Vegetable Pesticides Potentially Suppress Insect Attacks of Short Age Plant Pests. Journal of Science and Health. 1(9): 465-469.

9. Yubin, J.I., Y. Miao, W. Bing and Z. Yao. 2014. The extraction, separation and purification of alkaloids in the natural medicine. Journal of Chemical and Pharmaceutical Research. 6(1):338-345.

10. Nurwidayati, A. 2012. The phytochemical screening and thin layer chromatography results of Jatrophagossypiifolia seeds. Health Science Journal of Indonesia. 3(2):27-31.

11. Yanti, S. and Y. Vera. 2019. Skrining Fitokimia Ekstrak Daun Belimbing Wuluh ( Averrhoa Bilimbi). Indonesian Health Scientific Journal. 4(2):41-46.

12. Syahadat, A. dan N. Siregar. 2020. Skrining Fitokimia Daun Katuk (Sauropus androgynus) Sebagai Pelancar Asi. Ndonesian Health Scientific Journal. 5(1):85-89.

13. Ramadhani, A., S. Saadah and S. Sogandi. 2021. Efek Antibakteri Ekstrak Daun Cengkeh (Syzygium aromaticum) Terhadap Escherichia coli dan Staphylococcus aureus. Jurnal Bioteknologi \& Biosains Indonesia (JBBI). 7(2): :203-214.

14. Ergina, S. Nuryanti dan I.D. Pursitasari. 2014. Uji Kualitatif Senyawa Metabolit Sekunder Pada Daun Palado (Agave angustifolia) yang Diekstraksi Dengan Pelarut Air dan Etanol.Jurnal Akademika Kimia. 3(3): 165-172

15. Setyawaty, R., R. Aptuning B and Dewanto. 2020. Preliminary Studies on the Content of Phytochemical Compounds On Skin of Salak Fruit (Salacca zalacca). Pharmaceutical Journal of Indonesia. 6(1):1-6.
16. Prayoga, D. G. K., K.A. Nocianitri dan N.N. Puspawati. 2019. Identifikasi Senyawa Fitokimia dan Aktivitas Antioksidan Ekstrak Kasar Daun Pepe (Gymnema reticulatum Br.) pada Berbagai Jenis Pelarut. Jurnal Ilmu dan Teknologi Pangan. 8(2):111-121

17. Novitasari, A.E. and D.Z. Putri. 2016. Identifikasi Senyawa Fitokimia Dan Aktivitas Antioksidan Ekstrak Kasar Daun Pepe (Gymnema reticulatum Br.) Pada Berbagai Jenis Pelarut. Jurnal Sains. 6(12):1014.

18. Agarwal, M., M.K. Agarwal, N. Shrivastav, S. Pandey, R. Das and P. Gaur. 2018. Preparation of Chitosan Nanoparticles and their In-vitro Characterization. Int. J. Life Sci. Scienti. Res. 4(2):1713-1720.

19. Pande, M., A. N. Bhaskarwar. 2016. Nanoparticles: Preparation and Characterization. Momentum Press. New York. 22-23

20. Taurina, W. R. Sari, U.C. Hafinur, S. Wahdaningsih, Isnindar. 2017. Optimasi Kecepatan dan Lama Pengadukan terhadap Ukuran Nanopartikel KitosanEkstrak Etanol 70\% Kulit Jeruk Siam (Citrus nobilis L. var Microcarpa). Trad. Med. J. 22(1): 16-20.

21. Laili, H.N., L. Winarti, L.O.R.K. Sari. 2014. Preparasi dan Karakterisasi Nanopartikel Kitosan-Naringenin dengan Variasi Rasio Massa KitosanNatrium Tripolifosfat. Pustaka Kesehatan.

22. Yadav, T.P., Yadav, R.M., Singh, D.P. 2012. Mechanical Milling: a Top Down Approach for the Synthesis of Nanomaterials and Nanocomposites. Nanosci. Nanotechnol., 2(3): 22-48.

23. Stadtlander, C.T.K. 2007. Scanning Electron Microscopy and Transmission Electron Microscopy of Mollicutes : Challenges and Opportunities, Modern Research and Educations Topics in Microscopy : USA. 29634

24. Choudhary, O.P. and Priyanka. 2017. Scanning Electron Microscope: Advantages and Disadvantages in Imaging Components. International Journal of Current Microbiology and Applied Sciences. 6(5): 18771882.

25. Kalishwaralal, K., V. Deepak, S. Ramkumarpandian, H. Nellaiah and G. Sangiliyandi. 2008. Extracellular Biosynthesis of Silver Nanoparticles by the Culture Supernatant of Bacillus licheniformis. Materials Letters. 62(29):4411-4413.

\section{GRAPHICAL ABSTRACT}

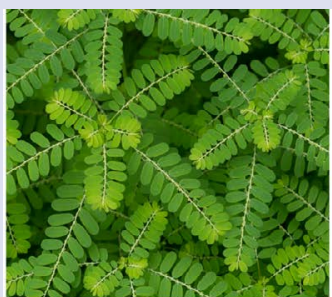

Phyllanthus niruri

\section{Extract's Nanoparticles}
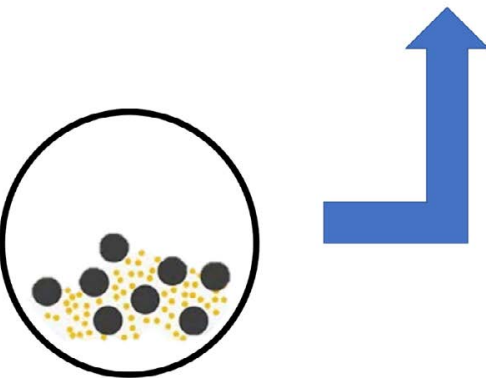

Ball Milling Method 


\section{ABOUT AUTHORS}

Emy Koestanti Sabdoningrum has conducted several research regarding the utilazation of Indonesia medicinal plants for enchancing animal productivity and health. She is one of members of Animal Husbandry Division in Faculty of Veterinary Medicine, Airlangga University, Indonesia.

Cite this article: Sabdoningrum EK, Hidanah S, Cusniati S, Soeharsono. Characterization and Phytochemical Screening of Meniran (Phyllanthus niruri Linn) Extract's Nanoparticles Used Ball Mill Method. Pharmacogn J. 2021;13(6)Suppl: $1568-1572$. 